\title{
Study and conservation of the Guiana dolphin (Sotalia guianensis) (Van Bénéden, 1864) in French Guiana
}

\author{
Amandine Bordin ${ }^{1,2, *}$, Margot Vanhoucke ${ }^{1,2}$, Kévin Pineau ${ }^{1,2}$, Laurent Kelle ${ }^{3}$, Nolwenn \\ Cozannet $^{3}$, Monique Pool ${ }^{4}$, Jaime Bolaños-Jiménez ${ }^{5,6}$, and Benoît de Thoisy ${ }^{7}$ \\ 'Groupe d'Etude et de Protection des Oiseaux en Guyane (GEPOG), 431 Route \\ d'Attila Cabassou, 97354 Rémire-Montjoly, French Guiana \\ ${ }^{2}$ Réserve Naturelle Nationale de I'lle du Grand-Connétable, 431 Route d'Attila \\ Cabassou, 97354 Rémire-Montjoly, French Guiana \\ ${ }^{3}$ World Wide Fund for Nature (WWF), 2 rue Gustave Charlery, 97300 Cayenne, French Guiana \\ ${ }^{4}$ Green Heritage Fund Suriname, Geertruida St 24, Paramaribo, Suriname \\ ${ }^{5}$ Asociacion Civil Sea Vida, A.P. 162, Cagua, Aragua, Venezuela 2122 \\ ${ }^{6}$ Caribbean-Wide Orca Project (CWOP), A.P. 162, Cagua, Aragua, Venezuela 2122 \\ ${ }^{7}$ Kwata NGO, 16 avenue Pasteur, 97300 Cayenne, French Guiana \\ *Corresponding author: amandine.bordin@gepog.org
}

\begin{abstract}
The Guiana dolphin (Sotalia guianensis) occurs in warm and shallow waters of the Atlantic Ocean and the Caribbean Sea, from southern Brazil to Honduras, including estuarine and freshwater habitats such as Maracaibo Lake (Venezuela), and the Orinoco River. In 2018, the Guiana dolphin was reclassified from Data Deficient to Near Threatened on the global IUCN Red List. Nevertheless, the conservation status identified by national and regional Red Lists is even more alarming. In French Guiana, for example, the species is classified as Endangered based on strong pressures such as bycatch. In this region, the Guiana dolphin inhabits river mouths and coastal waters where most anthropogenic activities occur. Better knowledge of the biology and ecology is needed in French Guiana to help inform effective conservation actions. Here, we present ongoing studies to map the distribution of Guiana dolphins along the French Guiana
\end{abstract}

Keywords:

Line-transects, aerial surveys, boat-based surveys, distribution abundance, bycatch, conservation issues

\section{ARTICLE INFO}

Manuscript type: Article

\section{Article History}

Received: 18 September 2021

Received in revised form: 29 October 2021

Accepted: 30 October 2021

Available online: 18 February 2022

\section{Responsible Editor: Miriam Marmontel}

Citation:

Bordin, A., Vanhoucke, M., Pineau, K., Kelle, L., Cozannet, N., Pool, M., Bolaños-Jiménez, J. and de Thoisy, B. (2022) Study and conservation of the Guiana dolphin (Sotalia guianensis) (Van Bénéden, 1864) in French Guiana. Latin American Journal of Aquatic Mammals 17(1): 10-21. https://doi.org/10.5597/lajam00276 coast and estimate abundance in a hotspot area. Aerial survey campaigns were conducted during the dry season in 2013,2014, 2015 , and 2019. Eight flights were conducted and 146 dolphins belonging to 39 groups were observed. Boat-based line-transect surveys were also conducted in the coastal waters of Cayenne in 2017 and 2018. Twenty-one survey trips were conducted covering $999.06 \mathrm{~km}$. Three hundred and eighty-two dolphins belonging to 63 groups were observed. The total abundance in the Cayenne area was estimated at 128 dolphins $(\% \mathrm{CV}=30.92 ; \mathrm{Cl}(95 \%)=$ $70-235)$ with a density of 0.80 ind. $/ \mathrm{km}^{2}(\% \mathrm{CV}=30.92 ; \mathrm{Cl}(95 \%)$ $=0.44-1.47$ ). Additionally, a descriptive analysis was performed on stranding data collected in French Guiana between 2014 and 2020 to identify the major cause of death and seasonality in the stranding events. In total, 43 dolphins were found, especially on the beaches of Rémire-Montjoly, Cayenne, and Kourou: bycatch was the major identifiable cause of death. We recommend a local conservation strategy and actions to be undertaken in the short- and medium-term to address different issues: knowledge, threats, conservation, and cooperation.

\section{Introduction}

The Guiana dolphin (Sotalia guianensis) (Van Bénéden, 1864) is a small Neotropical delphinid endemic to the eastern coast of South and Central America (Rice, 2002; Secchi et al., 2018). It occurs in warm and shallow waters in open bays, estuaries, and river mouths from Florianópolis, Santa Catarina state, southern Brazil $\left(27^{\circ} 35^{\prime}\right.$ $S, 48^{\circ} 35^{\prime}$ W), with a continuous distribution northwards in the Caribbean Sea and along the coast of Central America, to central Honduras ( $15^{\circ} 58^{\prime} \mathrm{N}, 79^{\circ} 54^{\prime} \mathrm{W}$ ) (Carr and Bonde, 2000; Edwards and Schnell, 2001; da Silva et al. 2010; Secchi et al., 2018). Within populations, Guiana dolphins usually form small groups (Borobia et al., 1991; Flores and da Silva, 2009; da Silva et al., 2010) and have small home ranges (Flores and Bazzalo, 2004; Santos and Rosso, 2007; Oshima and Santos, 2016). Genetic population structure studies conducted along the coast of South America show strong differentiation between populations. However, genetic information is still lacking for Central America (Caballero et al., $2017 ; 2018$ ) and the Guiana Shield region (Domit et al., 2021). 
In French Guiana, the Guiana dolphin is observed along the entire coast, mainly on rocky sites and in the largest river mouths, such as the Maroni, Kourou, Cayenne, Mahury, Approuague, and Oyapock. The species is not observed beyond $36 \mathrm{~km}$ offshore (Mannocci et al., 2013) and $18 \mathrm{~km}$ upriver (two sightings recorded in the Cayenne and Mahury rivers in 2014, A. Bordin, pers. obs.). The main sites of species occurrence are close to areas with large human populations, estimated at about 270,000 inhabitants, most of whom live in the coastal zone (INSEE, 2019). Anthropogenic activities generate direct and indirect threats and pressures on dolphins. Every year, legal and illegal fishing causes several dolphin deaths as a result of bycatch (Van Waerebeek, 1990; French Guiana Stranding Network, 2020). The species may also be impacted by the degradation of coastal and marine environments caused by land-based sources of pollution, such as insufficiently purified wastewater, macro and micro-waste disposal, and gold panning associated chemical pollution (Brichet, 2009).

Locally, the National Nature Reserve of Grand-Connétable Island (created in 1992) and the Amana Nature Reserve (created in 1998) help protect part of the French Guianese waters, including the Guiana dolphin, which is present in their marine ecosystem. Local protection for marine mammals is reinforced by the Ministerial Decree as of 1 July 2011 that protects all marine mammals in national territory. Since 1982, Guiana dolphins have been listed on Appendix I of the Convention on International Trade in Endangered Species of Wild Fauna and Flora (CITES) and listed on Appendix II of the Convention on the Conservation of Migratory Species of Wild Animals (CMS) since 1985 (Crespo et al., 2010). This species is also included in Annex 2 of the Specially Protected Areas and Wildlife Protocol (SPAW) of the Cartagena Convention for Protected Species in the Wider Caribbean Region.

For many years, the International Union for Conservation of Nature (IUCN) listed the Guiana dolphin as Data Deficient. However, recently, the IUCN conservation status was reclassified as Near Threatened (Secchi et al., 2018) and several national and regional Red Lists have been assessed which have resulted in alarming conservation status assessments: Vulnerable in Brazil (ICMBio/MMA, 2018), Colombia (Rodríguez-Mahecha et al., 2006) and Venezuela (Barrios-Garrido et al., 2015), and Endangered in French Guiana (UICN France et al., 2017). In the latter, the main criteria for listing the species as Endangered was based on the high degree of pressure exerted on the species, from bycatch and habitat degradation, and the species assumed limited exchanges (due to sedentary groups and movements over short distances) with dolphin populations from neighboring countries (UICN France et al., 2017).

Knowledge on the biology, ecology, and behavior of S. guianensis in French Guiana is still very limited, but several initiatives have been carried out recently or are in progress. Here, we present current efforts to map the species distribution along the Guianese coast and to estimate its abundance and density in the coastal waters of Cayenne. We also present a preliminary and descriptive analysis of stranding data collected between 2014 and 2020 by the French Guiana Stranding Network, to identify the main areas where strandings occur, the major cause of death, and possible seasonal variations. Finally, we recommend a local conservation strategy and actions to be undertaken in the short- and medium-term under the framework provided by the
International Whaling Commission (IWC) report of the Sotalia guianensis pre-assessment workshop (Domit et al., 201 9; 2021), the United Nations Environment Programme's Marine Mammal Action Plan (UNEP/MMAP) (UNEP, 2008), and the Action Plan for South American River Dolphins (Trujillo et al., 2010).

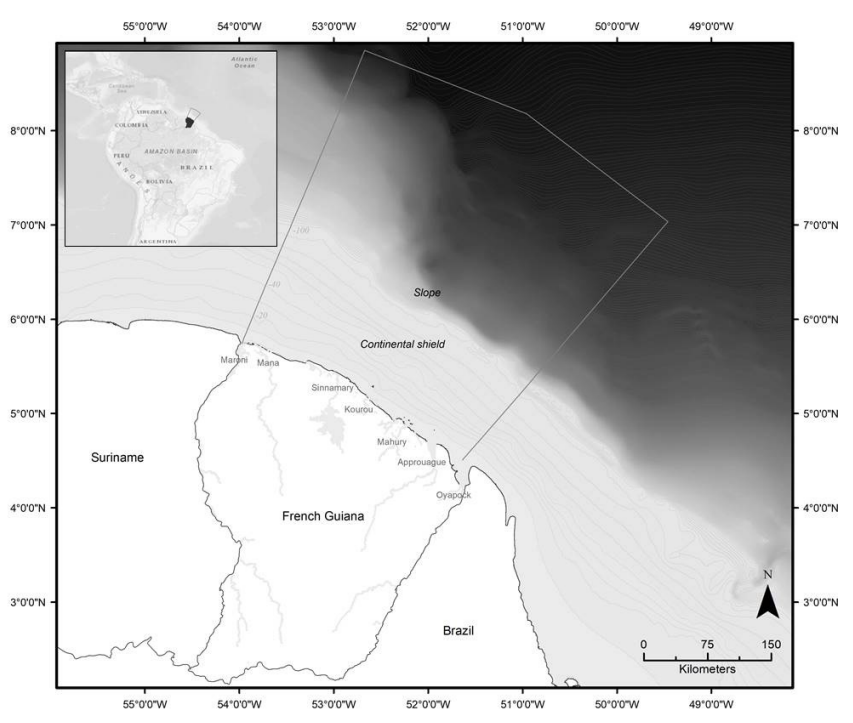

Figure 1. Exclusive Economic Zone and rivers of French Guiana (Base map: ESRI, www.gebco.net).

\section{Materials and method}

\section{French Guiana}

French Guiana is a French overseas territory located in the Equatorial zone of the Northern Hemisphere between $2^{\circ}$ and $7^{\circ} \mathrm{N}$, and $51^{\circ}$ and $54^{\circ} \mathrm{W}$ (Fig. 1). It is part of the Guiana Shield region bordering the Atlantic Ocean, including five other countries (Venezuela, Guyana, Suriname, as well as parts of Colombia and Brazil). French Guiana has an area of $86,504 \mathrm{~km}^{2}$ with a coastline of about $300 \mathrm{~km}$. Its Exclusive Economic Zone (EEZ) is almost $140,000 \mathrm{~km}^{2}$ in area (Barret, 2001).

Coastal and marine habitats of French Guiana are characterized by shallow depths with a gently declining continental shelf extending up to $150 \mathrm{~km}$ offshore (Boyé et al., 1979). Littoral and coastal environments are influenced by large rivers - Oyapock, Approuague, Mahury, Kourou, Sinnamary, Mana, Maroni - running from south to north, which discharge sediments and fresh water into the Atlantic Ocean. Eastward, the Amazon River in Brazil, through its massive, suspended sediment discharge, plays an important role in the composition of the estuarine, coastal, and shelf marine ecosystems (Artigas et al., 2003; Anthony et al., 2013). Under the combined influence of the Amazon River and Guiana Current, sediments produce huge mudflats that move westward and extend up to $60 \mathrm{~km}$ long, $30 \mathrm{~km}$ wide, and $5 \mathrm{~m}$ thick (Gensac, 2012). The coastal waters of French Guiana are thus subject to strong seasonal and inter-annual variations in turbidity and salinity.

The shoreline of French Guiana is mostly bordered by mangrove forests of Avicennia nitida along the coast and Rhizophora mangle in the estuaries (Battistini, 2003). French Guiana has around 10$30 \mathrm{~km}$ of beaches, which corresponds to less than $10 \%$ of the 
coastline, and hosts the only rocky habitats found between the Amazon and Orinoco rivers. These habitats are frequented by many top marine predators that use these areas as feeding and nursery grounds, such as Goliath groupers (Epinephelus itajara) (Artero et al., 2015), Atlantic tarpons (Megalops atlanticus) (Rohtla et al., 2016), Guiana dolphins (Mannocci et al., 2013), and other charismatic vertebrates including green turtles (Chambault et al., 2018) and Antillean manatees (Castelblanco-Martinez et al., 2018). The intense coastal dynamics create specific challenges for the long-term monitoring of marine turtles (Kelle et al., 2007) and potentially for all the megafauna species, like the Guiana dolphin, associated with this rapidly evolving ecosystem.

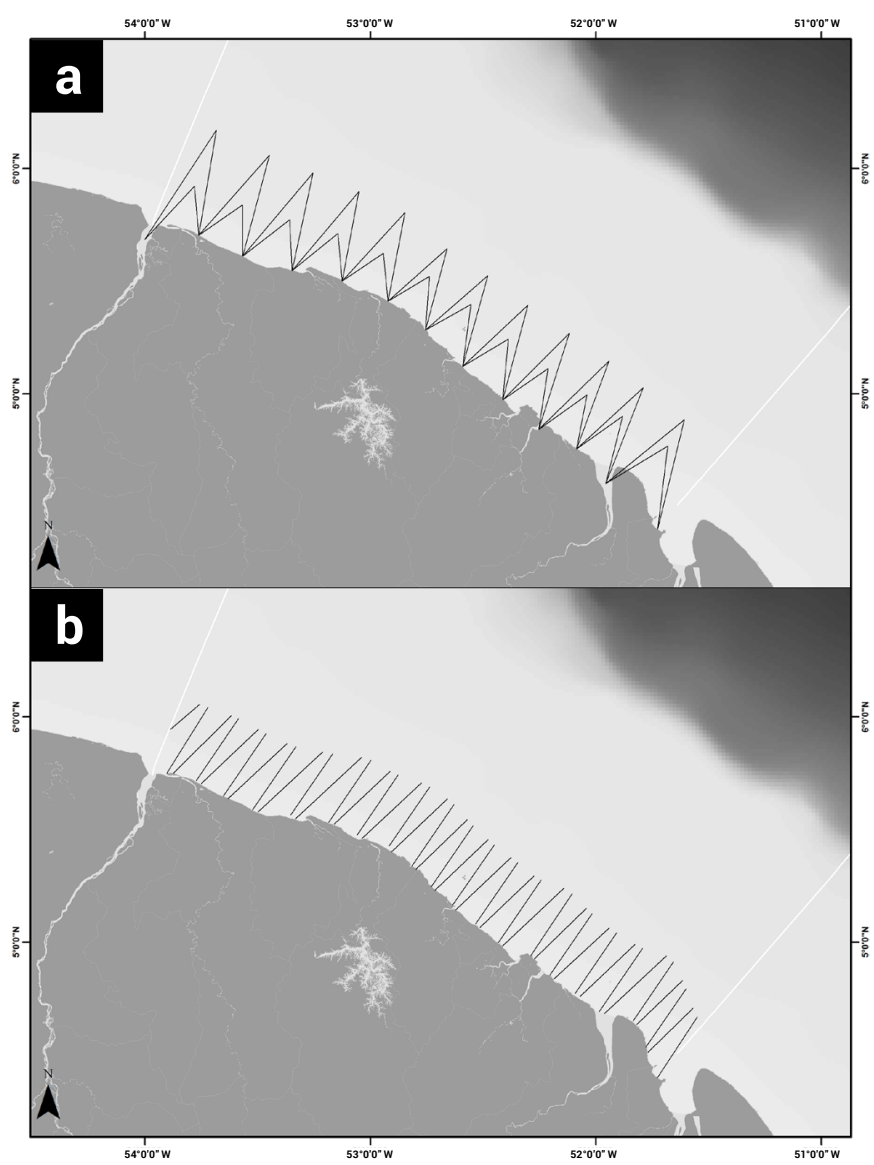

Figure 2. Survey transects from aerial surveys conducted between 2013 and 2019 along the French Guiana coast (a) by WWF/campaign 1 and (b) GEPOG/campaign 2 to assess Guiana dolphin abundance.

\section{Spatial distribution along the French Guiana coast \\ - Aerial surveys}

Between 2013 and 2015, the World Wide Fund for Nature (WWF) implemented the first aerial survey campaign (Campaign 1) dedicated to the census of the Guiana dolphin and its distribution along the French Guiana coast. The surveys occurred over three days in November 2013 and one day each in May 2014 and July 2015 (Table 1). The survey track covered 2,307 km (an area of approximately $2,500 \mathrm{~km}^{2}$ ) and the total survey effort was about 18 hours, including search, observation, and transit time (Fig. 2a). Transects of the neritic stratum were carried out once while those of the coastal stratum were replicated between one and three times, with more survey effort in the western part of the
Table 1. Effort and groups of Guiana dolphins observed during aerial campaigns 1 and 2 conducted in 2013, 2014, 2015 and 2019 in French Guiana.

\begin{tabular}{|c|c|c|c|c|c|}
\hline Date & Campaign & $\begin{array}{l}\text { Number } \\
\text { of lines }\end{array}$ & $\begin{array}{c}\mathrm{Km} \\
\text { travelled }\end{array}$ & Stratum & $\begin{array}{c}\text { Number of } \\
\text { groups (inds) }\end{array}$ \\
\hline 14 Nov 2013 & 1 & 8 & 390 & $\begin{array}{c}\text { Neritic } \\
\text { (east) }\end{array}$ & $3(5)$ \\
\hline 15 Nov 2013 & 1 & 8 & 418 & $\begin{array}{l}\text { Neritic } \\
\text { (west) }\end{array}$ & $7(11)$ \\
\hline \multirow[t]{2}{*}{16 Nov 2013} & 1 & 16 & 462 & $\begin{array}{c}\text { Coastal } \\
\text { (west + } \\
\text { east) }\end{array}$ & \multirow[t]{2}{*}{$9(27)$} \\
\hline & & 8 & 349 & $\begin{array}{l}\text { Neritic } \\
\text { (east) }\end{array}$ & \\
\hline 23 May 2014 & 1 & 12 & 316 & $\begin{array}{c}\text { Coastal } \\
\text { (west) }\end{array}$ & $3(7)$ \\
\hline $21 \mathrm{Jul} 2015$ & 1 & 14 & 372 & $\begin{array}{l}\text { Neritic } \\
\text { (east) }\end{array}$ & $10(24)$ \\
\hline 03 Oct 2019 & 2 & 20 & 727 & $\begin{array}{c}\text { Neritic } \\
\text { (east) }\end{array}$ & $2(4)$ \\
\hline 05 Oct 2019 & 2 & 20 & 744 & $\begin{array}{l}\text { Neritic } \\
\text { (west) }\end{array}$ & $1(9)$ \\
\hline \multirow[t]{2}{*}{06 Oct 2019} & 2 & 20 & 727 & $\begin{array}{c}\text { Neritic } \\
\text { (east) }\end{array}$ & $4(59)$ \\
\hline & & & 4,869 & & $39(146)$ \\
\hline
\end{tabular}

study area. In 2019, the Groupe d'Etude et de Protection des Oiseaux en Guyane - GEPOG (Study and Protection Group of Birds in French Guiana) and the National Marine Reserve of the Grand-Connétable Island also conducted aerial surveys under the framework of the European project CARI'MAM (Campaign 2) (Table 1). These surveys took place on three days in October 2019 during the dry season when the conditions were most favorable. The survey covered 2,198 km (approximately 2,500 km²) over about 12 hours (Fig. 2b). Transects were sampled one or two times. All surveys were carried out early in the morning to limit sun glare and when the sea state was equal to 3 or below on the Beaufort wind scale.

The transect design followed a zigzag profile that cut perpendicularly across the isobaths to sample different depths, allowing rapid coverage of a large area and optimizing flight time by limiting transits between transects. The Campaign 1 sampling included 48 transects for a total length of $1,837 \mathrm{~km}$. The sampling design consisted of a peri-coastal stratum with 24 transects extending to $20 \mathrm{~km}$ offshore (effort $=680 \mathrm{~km}$ ) and a neritic stratum with 24 transects extending to about $45 \mathrm{~km}$ above the $40 \mathrm{~m}$ depths (effort $=1,157 \mathrm{~km}$ ). The sampling design of Campaign 2 was slightly different with a single neritic stratum, including 40 transects closer together and extending to $40 \mathrm{~km}$ above depths of $30 \mathrm{~m}$, with a total length of $1,471 \mathrm{~km}$.

For both campaigns, the aircraft used was a twin-engine Britten Norman 2 (BN2) with high wings and equipped with two bubble windows so that observers could look below the aircraft. Its maximum flight time was approximately six hours. The aircraft maintained an altitude of $182 \mathrm{~m}$ (600 feet) above the water's surface and flew at a speed of $167 \mathrm{~km} / \mathrm{h}$ (90 knots). The crew was composed of five people, including a pilot, a navigator, a co-navigator, and two experienced observers. The navigator oversaw entering the data on a laptop computer equipped with SAMMOA software, specially developed for aerial surveys by the 
PELAGIS Observatory of La Rochelle University, and a GPS unit. A strip of about $1,000 \mathrm{~m}$ width was covered by the observers (500 $\mathrm{m}$ on each side of the plane). For each observation, the observer recorded the number of individuals, surface behavior, and swimming direction. Records related to human activities (boats, nets, macro-waste, and pollution) were also reported. The resulting distribution map was made with ArcGIS 10.8 ESRI software (ESRI, 2021).

\section{Abundance and density estimates in the coastal waters of Cayenne \\ - Boat-based line-transect surveys}

Boat-based line-transect surveys using the Distance Sampling method (Buckland et al., 1993; Thomas et al., 2010) were conducted to estimate the abundance and density of Guiana dolphins in the coastal and estuarine waters of Cayenne. The study area was bordered by two estuaries, the Cayenne River in the west and the Mahury River in the east (Fig. 3). It extended up to $10 \mathrm{~km}$ offshore and included a variety of habitats such as estuaries, mangroves, islands, and beachfronts over an area of $160 \mathrm{~km}^{2}$.

In total, 21 survey trips were carried out during the dry season (August, October, and November 2017; July and August 2018) (Table 2). The trips were conducted between 07:00 h and 14:00 $\mathrm{h}$ when conditions were most favorable, prior to increased afternoon wind activity (Beaufort sea state less than or equal to 3 , no rain). The sampling plan included 26 transects with an average length of $6 \mathrm{~km}(\min .=4.6 \mathrm{~km} ; \max .=10.5 \mathrm{~km})$ covering $999.06 \mathrm{~km}$ (Fig. 4). The transects were distributed throughout the study area and covered different habitats: estuaries, navigation channels, and rocky and muddy zones. The aircraft was oriented according to the direction of the swell and the geographical constraints of the study area (submerged rocks, islets, mudflats, etc.). The transects were carried out in succession to limit transit times. Each survey lasted approximately 4.5 hours, for a total of 100 hours, including search, observation, and transit time. The transects were replicated between 4 and 11 times (mean =6), with more effort in the eastern part of the study area.

Motorized boats ( $<7 \mathrm{~m}$ long) equipped with a GPS unit and depth sounder were used. The boat speed ranged between 14 and $22 \mathrm{~km} / \mathrm{h}$, faster than the swimming speed of dolphins $(7 \mathrm{~km} / \mathrm{h}$;

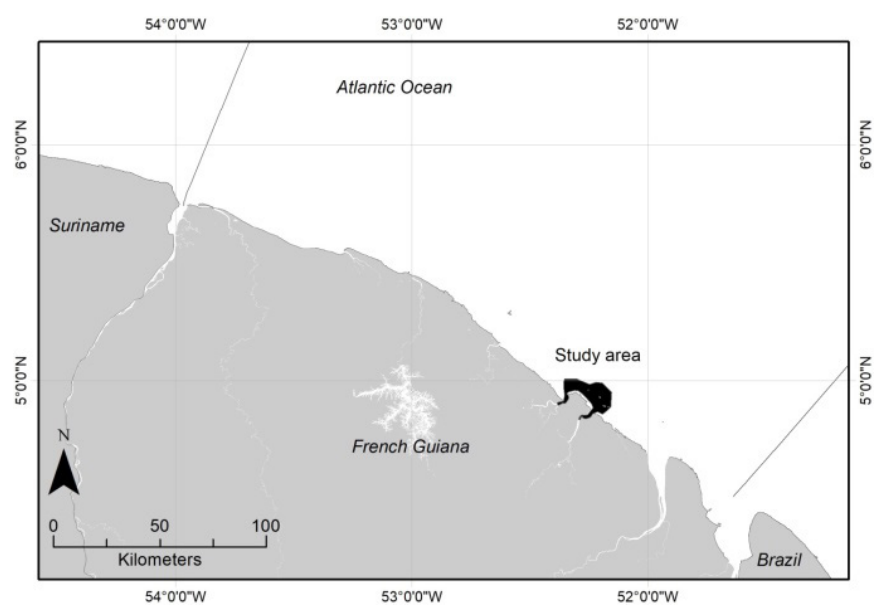

Figure 3. Study area of the boat-based line-transect surveys of Guiana dolphins in French Guiana, 2017-2018.
Table 2. Effort and groups of Guiana dolphins observed in linetransect surveys in 2017 and 2018 in the coastal waters of Cayenne, French Guiana.

\begin{tabular}{cccc}
\hline Year & Trips & Km travelled & Nbr groups (inds) \\
\hline 2017 & 9 & 341.03 & $22(146)$ \\
2018 & 12 & 658.03 & $37(225)$ \\
\cline { 2 - 4 } Total & 21 & 999.06 & $59(371)$ \\
\hline
\end{tabular}

Cremer et al., 2000). Two trained observers were placed at the front of the boat and surveyed $90^{\circ}$ each, for a $180^{\circ}$ total forward observation, over a band of $500 \mathrm{~m}$. Geographic coordinates of the observations were collected using a Garmin GPS unit. Starting in July 2018, a cellular iPad touchscreen tablet equipped with the OBSenMER application's expert component was used to record the tracks, observations, and conditions.

When a dolphin was detected, its geographic position was recorded when it was perpendicular to the boat and the animal's distance from the vessel was estimated by naked eye.

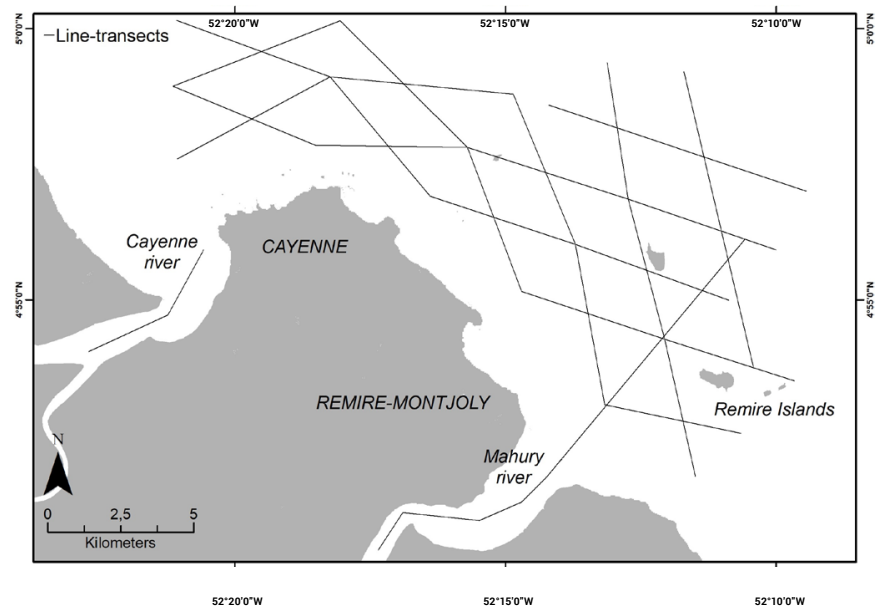

Figure 4. Boat-based line-transect surveys conducted between 2017 and 2018 in the coastal waters of Cayenne, French Guiana, to assess Guiana dolphin abundance.

The observers were previously trained to estimate distances using buoys and GPS. The information recorded which side of the vessel the observation occurred (right or left) and group size.

Data were spatially displayed using ArcGIS 10.8 (ESRI, 2021), and abundance and density analyses were performed using Distance 7.3 Release 1 (Thomas et al., 2010). Observations were grouped into distance intervals $(0-100 \mathrm{~m}, 100-200 \mathrm{~m}$, 200-300 m, 300-500 m) and those greater than $500 \mathrm{~m}$ were excluded from the analysis to refine the detection function per the recommendations of Buckland et al. (2001). The probability of detection was estimated using a Conventional Distance Sampling (CDS) approach. This method considers that the probability of detection decreases with greater distances between the $g(0)$ line and the observation. It is based on three assumptions, which can lead to potential bias if not considered: (1) all animals on the line are detected and the detection probability is assumed to be equal to $1(\mathrm{~g}(0)=1),(2)$ animals do not flee or be attracted by the survey platform, and (3) the distances are measured accurately (Buckland et al., 2001). Three key functions were tested (half-normal, hazard-rate, and uniform), both without adjustment 
and with Cosine adjustment. The detection function model was selected according to the minimum Akaike Information Criterion (AIC) (Akaike, 1985; Laake et al., 1993), and the fit of the detection function to the observed data was estimated with a GoodnessOf-Fit (GOF) test available in Distance software.

\section{Strandings}

A local branch of the French Stranding Network was created in 2014 to train and empower approximately 20 volunteers to respond to stranded animals in French Guiana. Between 2014 and 2020, the network responded to 43 strandings of Guiana dolphins, mainly on the beaches of Remire-Montjoly, Cayenne, and Kourou ( $86 \%$ of stranding records).

For each stranding event, geographic coordinates, species, sex, state of decomposition, number of teeth per jaw, and body measurements (length of the body, fins, rostrum, circumference, etc.) (Jauniaux et al., 2002) were recorded. Photos were taken, and an external examination followed. If the state of decomposition was not too advanced, a necropsy was performed to identify the cause of death. Banding marks, clear cuts, and antemortem haematomas usually indicate capture in a net. A descriptive analysis of the eight years of stranding data allowed us to identify spatial and temporal trends in stranding events and highlighted the main causes of death. An ANOVA test was run to determine whether the number of strandings varied by months (at a $5 \%$ significance level).

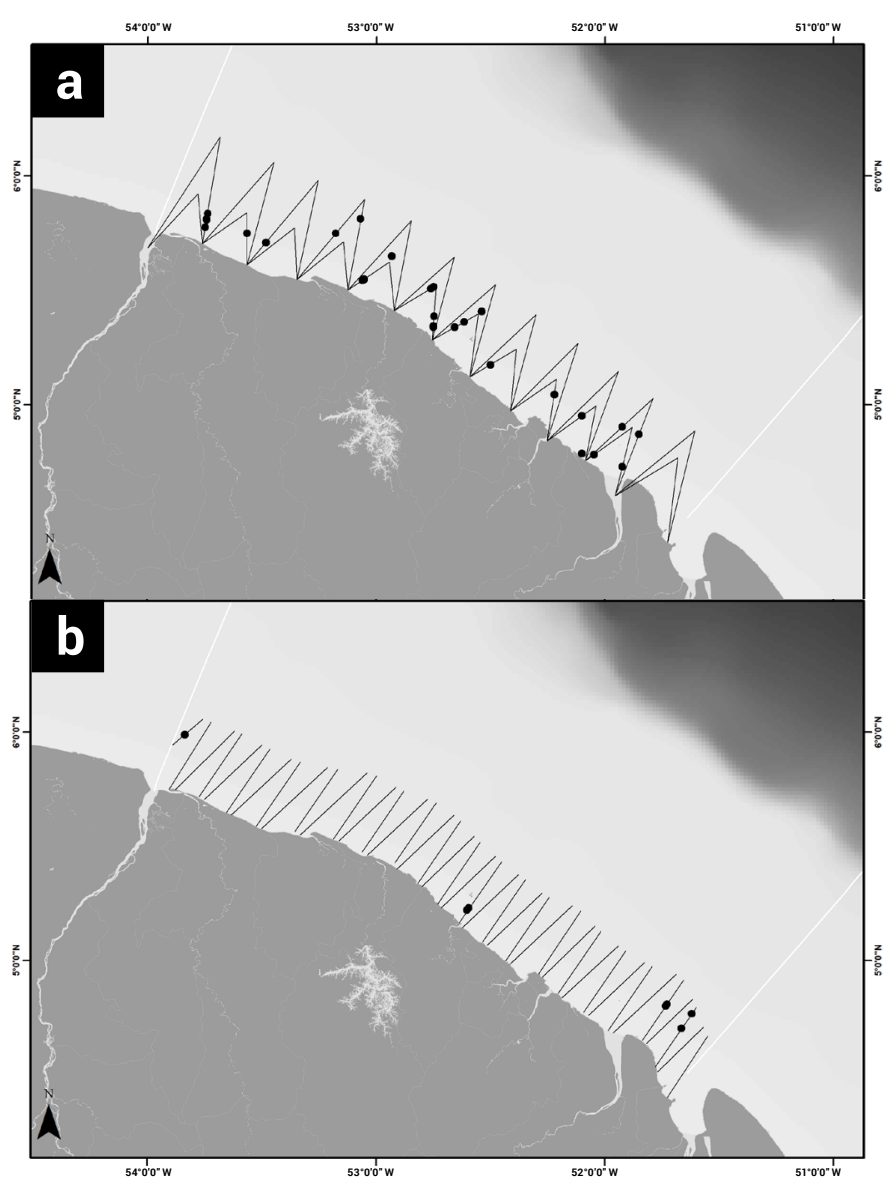

Figure 5. Location of the Guiana dolphin groups $(n=39)$ observed during (a) aerial campaign 1 and (b) aerial campaign 2 along the French Guiana coast, 2013-2019.

\section{Results}

\section{Spatial distribution}

A total of 74 Guiana dolphins belonging to 32 groups were observed during aerial campaign 1 (Fig. 5a) and 72 Guiana dolphins (7 groups) during Campaign 2 (Fig. 5b) (Table 1). Encounter rates were 3.21 individuals per $100 \mathrm{~km}$ travelled during Campaign 1 and 3.27 individuals per $100 \mathrm{~km}$ travelled for Campaign 2. Group sizes varied from 1 to 6 individuals (mean = 2.31, Campaign 1) and from 2 to 50 individuals (mean $=10.28$, Campaign 2). It should be noted that the Campaign 2 mean is equal to 4 when we remove the outlier group of 50 individuals due to the infrequency of groups of that size. The groups were observed in water depths from 2 to $28 \mathrm{~m}$, with a mean depth of $11 \mathrm{~m}$ for Campaign 1 and $14 \mathrm{~m}$ for Campaign 2 (Fig. 6). Most of the groups were located between $10 \mathrm{~km}$ and $23 \mathrm{~km}$ offshore. The group observed at the $28 \mathrm{~m}$ isobath was located $34 \mathrm{~km}$ offshore.

\section{Abundance and density estimates}

In total, 382 individual Guiana dolphins belonging to 63 groups were recorded during our line-transect surveys (Fig. 7). The encounter rate was $0.038 \mathrm{ind} . / 100 \mathrm{~km}$. Sightings of 371 individuals from 59 observations were used for abundance and density analyses after truncating the data to exclude sightings beyond $500 \mathrm{~m}$ (5\% of the dataset) (Table 2). Distance intervals of 0-100 $\mathrm{m}, 100-200 \mathrm{~m}, 200-300 \mathrm{~m}$, and $300-500 \mathrm{~m}$ included $25,18,9$, and 7 observations respectively. The model used for the detection function as determined by the lowest AIC was the Hazard-Rate model (AIC $=153.38)$, with a Cosine fit based on the better GOF (GOF = 0.90).

The abundance of dolphins using the waters of Cayenne was estimated to be 128 individuals $(\% \mathrm{CV}=30.92 ; \mathrm{Cl}(95 \%)=$ $70-235)$ with a density of 0.80 ind. $/ \mathrm{km}^{2}(\% \mathrm{CV}=30.92 ; \mathrm{Cl}(95 \%)$ $=0.44-1.47$ ).

Group sizes varied from 2 to 50 individuals. The average group size for the entire study area was 6.28 individuals $(C V=16.34 ; \mathrm{Cl}$ $(95 \%)=4.58-8.70)$. The effective detection width was estimated at $236.01 \mathrm{~m}$ (Fig. 8).

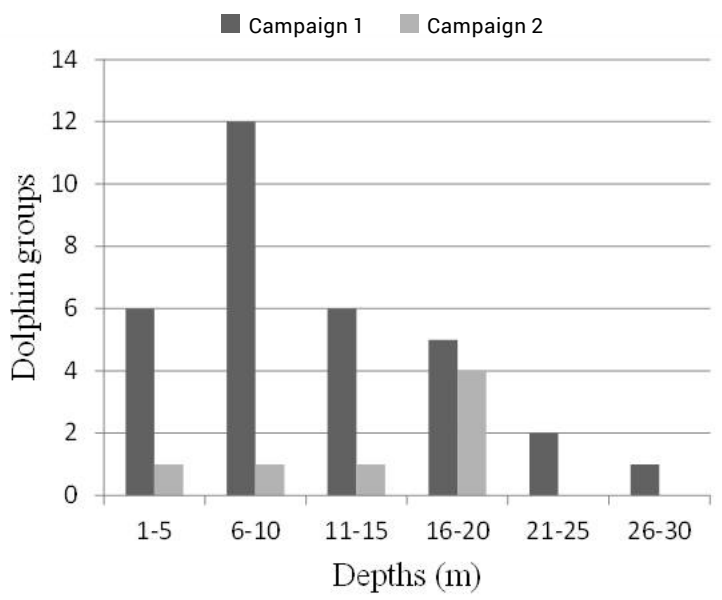

Figure 6. Depths $(\mathrm{m})$ of the Guiana dolphin observations recorded during aerial campaign 1 (depth mean $=11$ ) and aerial campaign 2 (depth mean $=14$ ) along the French Guiana coast, 2013-2019. 


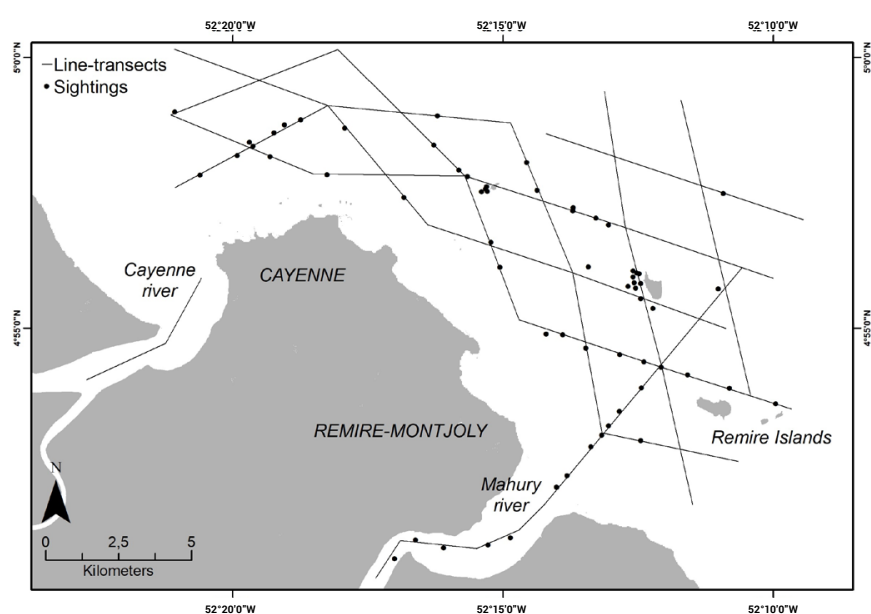

Figure 7. Location of the Guiana dolphin groups $(n=63)$ observed during the boat-based line-transect surveys in 2017 and 2018 in the coastal waters of Cayenne, French Guiana.

\section{Bycatch}

The French Guiana Stranding Network recorded 43 stranded Guiana dolphins between 2014 and 2020 (mean = 6/year), including one live-stranded neonate that did not survive. Twenty animals (46\%) were fresh with little decomposition, which allowed for external examinations and necropsy to facilitate determination of the cause of death. From 2014 to 2020, 26 individuals were killed from entanglement in fishing gear, representing $60.5 \%$ of strandings (annual mean $=3.7$ ) $($ Table 3 ). The catches were made either in the nets of the coastal artisanal fisheries or illegal foreign fisheries. The animals were mostly found on the beaches of Rémire-Montjoly, Cayenne, and Kourou (Table 4, Figs 1 and 4). The number of strandings averaged 3.6 per month, with very few individuals reported in July $(n=0)$ and August $(n=1)$, and higher numbers of individuals reported in March $(n=6)$, September $(n=6)$, and December $(n=7)$ (Fig. 9). The ANOVA test showed that the differences in the number of strandings by month were not significant ( $F$ ANOVA $=1.392 ; p=0.257$ ).

\section{Discussion}

Aerial surveys have been used in several areas to study small delphinids (Slooten et al., 2004; Lambert et al., 2019), but sparingly for Guiana dolphins. In Nicaragua, Carr and Bonde (2000) and Edwards and Schnell (2001) conducted aerial surveys, coupled with boat surveys, to assess the distribution of the species and its abundance. However, protocols of those studies (aircraft, speed, altitude, sampling designs) differed from those implemented in French Guiana, precluding further comparisons. Furthermore, standardized methods for estimating ecological parameters of populations are essential to compare results, monitor trends, and to establish conservation actions (Gomez-Salazar et al., 2012; Domit et al., 2019).

During the 2008 dry season in French Guiana, La Rochelle University carried out the EXOCET aerial campaign, which provided the first snapshot of the distribution and abundance of marine mammals and other megafauna species within the EEZ (Mannocci et al., 2013). During those surveys, 22 groups of Guiana dolphins

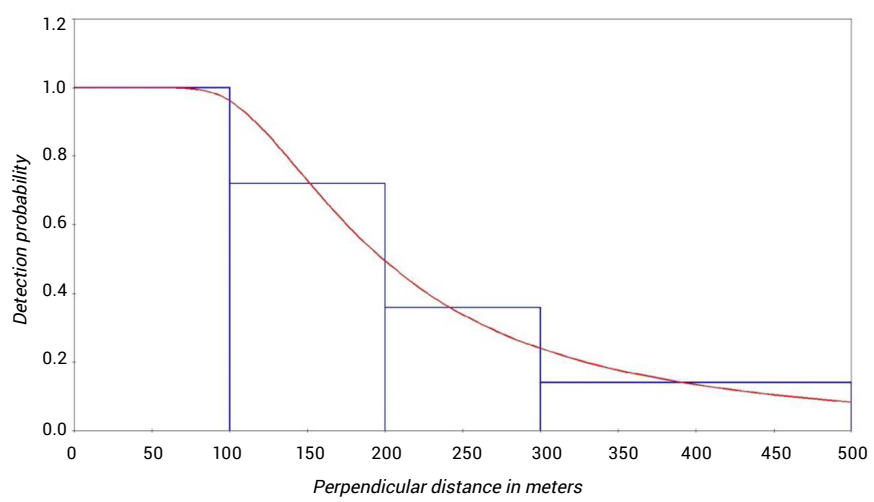

Figure 8. Detection probability of Guiana dolphin according to distance from the $g(0)$ line during survey effort. The curve represents the best detection function model.

( $n=59$ ) were observed during three flights with an average group size of $2.6(\min =1 ; \max =8)$.

Despite a similar survey effort (around $750 \mathrm{~km}$ covered in the coastal strip), the number of groups observed was higher during the EXOCET campaign and Campaign 1 than in Campaign 2; the encounter rates changed from 7.8 inds $/ 100 \mathrm{~km}$ in 2008 to 3.27 inds/100 km in 2019. The average group sizes remained consistent (if we exclude the observation of the group of 50 individuals in 2019, which is not common). Observations were more concentrated in shallow depths during the EXOCET campaign.

These changes over time could be explained partly by the variations in some of the environmental parameters such as bathymetry. Since 2014, a large westward-moving mudflat increased the sediment deposition rate in that area. Thus, animals could be forced to move towards the open water, especially during low tide. The land-based surveys conducted in 2014 and 2018 in French Guiana also confirmed a decrease in number of observations in the shallow waters $(<5 \mathrm{~m}$ ) (A. Bordin, unpub. data). The lower encounter rates could also be explained by the higher level of turbidity generated by the suspended sediments, which decreases the detection rate of individuals. Moreover, water temperature, salinity, prey distribution, and prey abundance can also influence the distribution of marine mammals (Vidal et al., 1997; Garcia and Trujillo, 2004; de Godoy et al., 2015; Tardin et al., 2020). In Nicaragua, the distribution and behavior of Guiana dolphins appear to be influenced by similar environmental

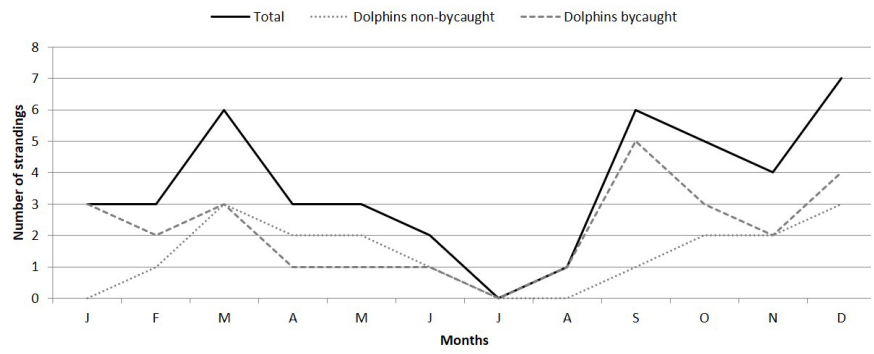

Figure 9. Number of strandings and number of bycaught Guiana dolphins per month between 2014 and 2020 along the French Guiana coast. 
Table 3. Number of bycaught and non-bycaught Guiana dolphins between 2014 and 2020 along the French Guiana coast.

\begin{tabular}{ccccc}
\hline & Bycatch & $\begin{array}{c}\text { No sign of } \\
\text { bycatch }\end{array}$ & Unknown & Total \\
\hline 2014 & 2 & - & - & 2 \\
2015 & 8 & - & 2 & 10 \\
2016 & 5 & - & 2 & 7 \\
2017 & 2 & - & 2 & 4 \\
2018 & 1 & - & 3 & 3 \\
2019 & 3 & 1 & 6 & 10 \\
2020 & 5 & - & 2 & 7 \\
Total & 26 & 1 & 17 & 43 \\
\hline
\end{tabular}

variables (Edwards and Schnell, 2001). A final hypothesis could be linked to a declining demographic trend. However, to confirm this, further surveys should be conducted over a longer time-period, including surveys to obtain abundance estimates.

An analysis of EXOCET data included a first estimate of the Guiana dolphin population as 1,968 individuals (IC 95\% = 938 4063) (Mannocci et al., 2013), but with a high standard deviation, meaning that this result should be taken with caution. Aerial surveys have several limitations for the census of small and coastal cetaceans in French Guiana. The size of the animals, their cryptic behavior at the water surface, and turbidity make them difficult to detect. Moreover, to obtain statistically sound results for abundance and density, the surveys must be replicated over a long time-period, requiring a considerable budget. In our case, and for these different reasons, we consider that the abundance estimate of Guiana dolphins by aerial surveys does not allow to obtain significant results and that other means should be considered. Aerial surveys using ultralight aircraft have been tested and could be an adequate solution to study the species distribution and abundance in its preferential habitats (A. Bordin, unpub. data). This aircraft is less expensive than a plane and can fly at a low altitude and speed, which facilitates the detection of animals. An ultralight aircraft was previously used for surveying marine turtle populations along the west coast of Reunion Island, Indian Ocean (Jean et al., 2010) and monitoring dugongs (Dugong dugon) in Mayotte, western Indian Ocean (Kiszka et al., 2007). In addition, the use of environmental data (bathymetry, salinity, temperature, distance to shore, etc.) and observation data would allow the realization of Ecological Niche Modeling (ENMs) in order to identify the favorable sites, or not, to the species along the coastline. Several studies have used this method, in particular to identify areas of interaction between animals and human activities, but also future marine protected areas (Tardin et al., 2020; Lobo et al., 2021).

The Distance Sampling method is the most used technique to estimate the abundance and density of the Guiana dolphin (Santos et al. 2010), even if the studies remain scarce along the range of the species. Thirty-six studies have been compiled between 2000 and 2019 (Domit et al. 2019), most of which were conducted in small areas in Brazil. The results obtained for the surveyed area in French Guiana $\left(160 \mathrm{~km}^{2}\right)$ show a density of 0.80 ind. $/ \mathrm{km}^{2}(\% \mathrm{CV}=30.92 ; \mathrm{Cl}(95 \%)=0.44-1.47)$. By comparing these results with those obtained in other areas, the density is quite low (Table 5). Data on Guiana dolphin ecology in French Guiana are limited, therefore data on abundance, a key factor in evaluating the conservation status and defining a management plan, are also limited. The only published abundance estimate for the entire population in French Guiana was that obtained from the EXOCET aerial surveys. In those surveys, the abundance estimate only considered a specific area or hotspot and the estimate was quite low (128 individuals (\% CV $=30.92 ; \mathrm{Cl}(95 \%)$ = 70-235) compared to other sectors (Table 5).

The reasons for the low density and abundance estimated in this study could be related to sampling bias because we did not respect all Conventional Distance Sampling assumptions. Accurate estimates of marine mammal densities and abundance are particularly difficult to obtain. Sampling biases can lead to inaccurate estimates because dolphins respond to the platform, therefore group size estimates are imprecise and affected by the detection rate (Buckland et al., 1993; Edwards and Schnell, 2001). In our research, the detection probability along the $g(0)$ line was assumed to be equal to 1 , because of the slow speed of the vessel, the favorable survey conditions, estimated dive time of 30 seconds for this species (Cremer et al., 2000; 2011), and shallow depth of the habitat. The animals were not attracted to the boat and those with an avoidance response were quickly detected. However, perpendicular distance estimation by naked eye can generate biases in abundance and density estimates, and can also lead to fitting an inappropriate detection function. In our study, distance estimation and measurement methods requiring the horizon were not possible since we were in a restricted area (Williams et al., 2007) and we used low platforms (Williams et al., 2017). Williams et al. (2007) compared different distance estimation methods in four experiments, including a study on dolphins in the Amazon River. The latter compares visual estimates and laser rangefinder measurements, and shows that

Table 4. Location of strandings of Guiana dolphins between 2014 and 2020 on the beaches of French Guiana and at sea.

\begin{tabular}{|c|c|c|c|c|c|c|c|}
\hline & Awala-Yalimapo & Kourou & Macouria & Cayenne & Rémire-Montjoly & At sea & Total \\
\hline 2014 & - & - & - & - & 2 & - & 2 \\
\hline 2015 & 1 & 5 & - & 1 & 3 & - & 10 \\
\hline 2016 & - & 1 & - & 1 & 3 & 2 & 7 \\
\hline 2017 & - & 3 & - & - & 1 & - & 4 \\
\hline 2018 & - & 2 & - & 1 & - & - & 3 \\
\hline 2019 & - & 2 & 2 & 1 & 5 & - & 10 \\
\hline 2020 & - & 2 & 1 & 1 & 3 & - & 7 \\
\hline $\begin{array}{c}\text { Total } \\
(\%)\end{array}$ & $\begin{array}{c}1 \\
(2 \%) \\
\end{array}$ & $\begin{array}{c}15 \\
(35 \%)\end{array}$ & $\begin{array}{c}3 \\
(7 \%)\end{array}$ & $\begin{array}{c}5 \\
(12 \%)\end{array}$ & $\begin{array}{c}17 \\
(39 \%)\end{array}$ & $\begin{array}{c}2 \\
(5 \%)\end{array}$ & $\begin{array}{c}43 \\
(100 \%) \\
\end{array}$ \\
\hline
\end{tabular}


errors could bias distance estimates downward by as much as $14 \%$ with naked eye estimation. Thus, measurements in future line-transect surveys must be made using laser rangefinders.

The confidence interval obtained for the abundance estimate is particularly large, which underlines a certain fragility of the dataset. The reasons are certainly related to an insufficient number of observations, and also due to methodological weaknesses. To reduce this confidence interval, additional survey trips should be conducted including a better coverage of the western part of the study area which was under-sampled. Indeed, the sampling design was extended beyond the Remire islands in 2018 to respond to a project of the French Guiana commercial harbor about the presence of the Guiana dolphin in the site. This project was a good funding opportunity, but increased the effort in the eastern part. A higher platform and the use of laser rangefinders should help limit bias in future estimates.

In addition to line-transect surveys, mark-recapture methods are regularly used to estimate the abundance of many marine mammal species and have largely demonstrated their effectiveness (Nery et al. 2008; Cantor et al., 2012; Coimbra et al., 2016; de Mello et al., 2019). A long-term photo-identification monitoring program in Sepetiba Bay in Brazil provided unbiased and more precise estimates of population size than those derived from line-transect surveys (Nery et al., 2008). Daura-Jorge and Simões-Lopes (2016) compared both approaches and showed that mark-recapture methods were twice as effective in terms of precision.

In most areas, group size for Guiana dolphin ranges from 2-29 individuals (Geise, 1991; Edwards and Schnell, 2001; Garcia and Trujillo, 2004; Daura-Jorge et al., 2007, Cremer et al., 2011). Here, the group size was estimated from line-transect surveys to be 6.28 individuals, twice as much as during the aerial campaigns. This may be explained by a lower detection of animals during the aerial surveys, and a better detection of large groups by boat (Dawson et al., 2008). Group size can be influenced by physical and environmental parameters, but also by feeding strategies and predation risk in the area (de Meirelles et al., 2020). The large groups (50-400 individuals) observed in the southern limit of the species distribution are explained by high availability of prey owing to the presence of large rivers and estuaries that can support large numbers of species and resources (Edwards and Schnell, 2001; Flores et al., 2018). High numbers of Sotalia, as found in some sections of the Amazon or Nicaragua, were the result of different factors such as a high abundance of prey, proximity to the resources, depth, water temperature, and salinity (Vidal et al., 1997; Edwards and Schnell, 2001).

An understanding of the pressures, both natural and anthropogenic, that can affect populations is essential for the conservation of vulnerable species and their habitats. Eleven anthropogenic activities with direct and indirect effects on the Guiana dolphin, including fisheries interactions, coastal infrastructure development, and port activities, have been identified throughout its range (Domit et al., 2019). Several of these pressures have been identified in French Guiana, including impacts from bycatch (Van Waerebeek, 1990; UICN France et al., 2017). Bycatch of dolphins (Guiana and bottlenose dolphins Tursiops truncatus) in offshore Guianese waters was first reported after interviews with fishers. These interviews indicated that impacts to the population could be considerable, and a hundred individuals could be taken each year (Van Waerebeek, 1990). Since 2014, the monitoring conducted by the French Guiana Stranding Network has shown that $60.5 \%$ of strandings are caused by incidental capture in fishing nets and that the annual numbers do not tend to decrease. The number of strandings could be larger since those found represent only a small proportion of total stranding events. Indeed, the accessible beaches represent around 5\% of the coastline, the rest being mangrove swamps or isolated beaches. The high rate of siltation could also block the carcasses on the mudflats and thus limit the number of strandings on the beaches. Moreover, the cause of death was undetermined for 17 animals, partly due to the advanced state of decomposition. In French Guiana, humidity, sun, rain, and black vultures (Coragyps atratus) may accelerate the decomposition rate of corpses.

The catches were all accidental; no cases of poaching were noted. In 2019, fishers who captured a Guiana dolphin declared having extracted and used pieces of blubber for bait. Even if this case is anecdotal, the practice was already observed in other stranding cases in French Guiana (Van Waerebeek, 1990).

Peaks of bycatch were noted in March, September, and December, which could be correlated with an increase in fishing activity in the area because of the more favorable sea and weather conditions. A detailed study to overlay the fisheries and distribution data of the dolphins would allow a better understanding of the interactions. Gillnets appear to be the type of gear that generates the most interactions with the Guiana dolphin (Bolaños-Jiménez and Rojas-Bracho, 2005; Domit et al., 2019). Brazilian fishermen operating in the Guianese

Table 5. Density/abundance estimates of Guiana dolphin in areas other than French Guiana.

\begin{tabular}{|c|c|c|c|c|c|}
\hline Study area, country & Technique & $\begin{array}{c}\text { Area surface } \\
\left(\mathbf{k m}^{2}\right)\end{array}$ & $\begin{array}{l}\text { Density } \\
\text { (ind.//km²) }\end{array}$ & Abundance & Source \\
\hline Cayos Miskito Reserve, Nicaragua & Boat survey/strip-transect & 152.4 & 0.6 & - & Edwards and Schnell, 2001 \\
\hline Gulf of Morrosquillo, Colombia & Boat survey/mark-recapture & 310 & 0.74 & $118-426$ & Dussán-Duque, 2013 \\
\hline Southern Gulf of Venezuela, Venezuela & Boat survey/follow-group protocol & 6.33 & 1.34 & $150-573$ & Espinoza-Rodríguez et al ., 2019 \\
\hline Maracaibo Lake System, Venzuela & Boat survey/mark-recapture & 249.2 & 1.66 & - & $\begin{array}{c}\text { Delgado-Ortega, } 2012 \\
\text { (in Barrios-Garrido et al ., 2021) }\end{array}$ \\
\hline Guanabarra Bay, Brazil & Boat survey/line-transect & 70 & 5.7 & - & Geise, 1991 \\
\hline Sepetiba Bay, Brazil & Boat survey/mark-recapture & 520 & - & $588-1004$ & $\begin{array}{c}\text { Flach, } 2015 \\
\text { (in Domit et al ., 2019) }\end{array}$ \\
\hline Paranaguá Bay, Brazil & Boat survey/line-transect & 38.84 & 11.56 & 1 & Filla, 2004 \\
\hline Babitonga Bay, Brazil & Boat survey/line-transect & 160 & 1.3 & $147-365$ & Cremer, 2011 \\
\hline
\end{tabular}


waters had reported incidental catches of dolphins in largemesh multifilament nylon nets (Van Waerebeek, 1990). Although bycatch rates or fishing efforts, particularly for the artisanal fishery, remain poorly known, few initiatives and experiments have been carried out on the Guiana dolphin to limit interactions with fisheries (Domit et al., 2019). From 1996 to 1998, an experimental test with pingers was conducted in Brazil by Monteiro-Neto et al. (2004). In 2018 in French Guiana, a project led by WWF and the Regional Committee of Fisheries was conducted to obtain information from fishers on the number of bycatches, frequency and location, and mitigation strategies which could be put in place to limit interactions (André, 2018).

Since the Guiana dolphin has a limited global distribution, France has a special responsibility regarding the study and preservation of this species in the Guianese territory. Consequently, research on S. guianensis in French Guiana should continue to help assess the impact of anthropogenic pressures on the local populations and help define the most effective means of protecting the species and its habitat. Efforts should be allocated for strengthening a regional conservation dynamic and the implementation of a National Action Plan that complies with actions promoted by the UNEP's MMAP (UNEP, 2008), the IWC's reports (Domit et al., 2019; 2021; IWC, 2021), and with specific conservation plans such as the Action Plan for South American River Dolphins 2010-2020 (Trujillo et al., 2010). Improving knowledge of abundance and density, spatial and temporal distribution, social parameters, and pressures is essential. Raising the awareness of the local communities and the development of participatory studies are also actions that should be promoted. Conservation actions, such as the development of marine protected areas, which represent less than $1 \%$ of the EEZ surface in French Guiana, should be considered to protect habitats favorable to the species, e.g. rocky habitats. These efforts will need to integrate fishers and other stakeholders to reconcile the preservation of marine biodiversity and economic activities. In addition, cooperation with networks in Brazil, the Guianas, Venezuela, Colombia, and Central America should be developed to standardize data collection and strengthen capabilities at local levels.

\section{Acknowledgments}

The aerial surveys were funded by the Regional Cooperation Fund/Prefecture of French Guiana and the General Directorate for Territories and the Sea of French Guiana (Campaign 1), and the FEDER Interreg - European Territorial Cooperation and the AGOA Sanctuary within the framework of the project CARI'MAM led by the French Biodiversity Agency (Campaign 2). The boat surveys were funded by the FEDER - European Regional Development Fund and the General Directorate for Territories and the Sea of French Guiana within the framework of the COAST project led by WWF and GEPOG. In 2018, a part of boat surveys was funded by the Grand Port Maritime of French Guiana. We wish to thank the first coordinators of the French Guiana Stranding Network Claire Pusineri (Ocean Science Logistic) and Virginie dos Reis (Kwata NGO), as well as other volunteers: Rachel Berzins and Ondine Rux (Office Français de la Biodiversité), Adrian Levrel and Shirley Aurélien (WWF France), and Ronald Wongsopawiro (Amana Nature Reserve). Finally, we are grateful to Hélène Delvaux-Rousseau for her support in the realization of these scientific projects and the volunteers for their help with data collection during the sea campaigns.

\section{References}

Akaike, H. (1985) Prediction and entropy. Pages 1-24 in Atkinson, A.C. and Fienberg, A.E. (Eds) A Celebration of Statistics. Springer, New-York, USA.

André, V. (2018) Projet PALICA: Pêcheries Actives pour la Limitation des Interactions et des Captures Accidentelles. Rapport final. WWF/CRPMEM/Fonds Européen pour les Affaires Maritimes et la Pêche/Ministère de l'Agriculture et de l'Alimentation. 80 pp.

Anthony, E.J., Gardel, A., Proisy, C., Fromard, F., Gensac, E., Peron, C., Walcker, R. and Lesourd, S. (2013) The role of fluvial sediment supply and river-mouth hydrology in the dynamics of the muddy, Amazon-dominated Amapá-Guianas coast, South America: A three-point research agenda. Journal of South American Earth Sciences 44: 18-24. https://doi.org/10.1016/j. jsames.2012.06.005

Artero, C., Koenig, C.C., Richard, P., Berzins, R., Guillou, G., Bouchon, C. and Lampert, L. (2015) Ontogenetic dietary and habitat shifts in Goliath grouper Epinephelus itajara from French Guiana. Endangered Species Research 27: 155-168. https:// doi.org/10.3354/esr00661

Artigas, L.F., Vendeville, P., Leopold, M., Guiral, D. and Ternon, J-F. (2003) Marine biodiversity in French Guiana: Estuarine, coastal, and shelf ecosystems under the influence of Amazonian waters. Gayana 67: 302-326. https://doi.org/10.4067/S071765382003000200013

Barret, J. (2001) Atlas illustré de la Guyane. Laboratoire de cartographie de la Guyane, Institut d'enseignement supérieur de Guyane, Agence Régionale d'Urbanisme et d'Aménagement de la Guyane, France. 219 pp.

Barrios-Garrido, H., Boher-Bentti, S., de Turris-Morales, K., EspinozaRodríguez, N.E., Ferrer-Pérez, A., Herrera-Trujillo, O.L., León, T., Oviedo, L., Pirela, D., Portocarrero-Aya, M., Sánchez-Criollo, L., Trujillo, F. and Bolaños-Jiménez, J. (2015) Tonina costera, Sotalia guianensis. Pages 1-5 in Rodriguez, J.P., Garcia-Rawlins, A. and Rojas-Suarez, F. (Eds) Libro Rojo de la Fauna Venezolana. Fundación Empresas Polar, Caracas, Venezuela.

Barrios-Garrido, H., de Turris-Morales, K. and Espinoza-Rodríguez, N.E. (2021) Guiana dolphin (Sotalia guianensis) in the Maracaibo Lake System, Venezuela: Conservation, threats and population overview. Frontiers in Marine Science 7: 594021. https://doi. org/10.3389/fmars.2020.594021

Battistini, R. (2003) Caractères généraux des mangroves de la Guyane française: Comparaison avec les mangroves malgaches. Comprendre et gérer la nature littorale. Cahier nantais 59: 131-138.

Bolaños-Jiménez, J. and Rojas-Bracho, L. (2005) A review of fisheries bycatch of marine mammals in the Widder Caribbean Region. Regional workshop of experts on the development of the Marine Mammal Action Plan for the Wider Caribbean Region. Bridgetown, Barbados, 18-21 July 2005. 
Borobia, M., Siciliano, S., Lodi, L. and Hoek, W. (1991) Distribution of the South American dolphin Sotalia fluviatilis. Canadian Journal of Zoology 69(4): 1025-1039. https://doi.org/10.1139/ z91-148

Boyé, M., Réaud, G. and Cabaussel, G. (1979) Atlas des départements français d'outre-mer. La Guyane. Volume 4. Centre d'Etudes de Géographie Tropicale du CNRS, Bordeaux-Talence. $88 \mathrm{pp}$.

Brichet, M. (2009) Analyse Stratégique Régionale. Agence des Aires Marines Protégées, France. 156 pp.

Buckland, S.T., Anderson, D.R., Burnham, K.P. and Laake, J.L. (1993) Distance Sampling: Estimating abundance of biological populations. Chapman and Hall, New-York, USA.

Buckland, S.T., Anderson, D.R., Burnham, K.P., Laake, J.L., Borchers, D.L. and Thomas, L. (2001) Introduction to Distance Sampling: Estimating abundance of biological populations. Oxford University Press, Oxford, UK.

Caballero, S., Trujillo, F., de Risco, A., Herrera, O. and Ferrer, A. (2017) Genetic identity of Sotalia dolphins from the Orinoco River. Marine Mammal Science 33(4): 1214-1223. https://doi. org/10.1111/mms.12422

Caballero, S., Hollatz, C., Rodríguez, S., Trujillo, F. and Baker, C.S. (2018) Population structure of riverine and coastal dolphins Sotalia fluviatilis and Sotalia guianensis: Patterns of nuclear and mitochondrial diversity and implications for conservation. Journal of Heredity 109(7): 757-770. https://doi.org/10.1093/ jhered/esy049

Cantor, M., Wedekin, L.L., Daura-Jorge, F.G., Rossi-Santos, M.R. and Simões-Lopes, P.C. (2012) Assessing population parameters and trends of Guiana dolphins (Sotalia guianensis): An eightyear mark-recapture study. Marine Mammal Science 28(1): 63-83. https://doi.org/10.1111/j.1748-7692.2010.00456.x

Carr, T. and Bonde, R.K. (2000) Tucuxi (Sotalia fluviatilis) occurs in Nicaragua, $800 \mathrm{~km}$ north of its previously known range. Marine Mammal Science 16: 447-452. https://doi. org/10.1111/j.1748-7692.2000.tb00936.x

Castelblanco-Martinez, N., Dos Reis, V. and de Thoisy, B. (2018) How to detect an elusive aquatic mammal in complex environments? A study of the Endangered Antillean manatee Trichechus manatus manatus in French Guiana. Oryx 52(2): 382-392. https://doi. org/10.1017/S0030605316000922

Chambault, P., de Thoisy, B., Huguin, M., Martin, J., Bonola, M., Etienne, D., Gresser, J., Hiélard, G., Mailles, J., Védie, F., Barnerias, C., Sutter, E., Guillemot, B., Dumont Dayot, E., Régis, S., Lecerf, N., Lefebvre, F., Frouin, C., Aubert, N., Guimera, C., Bordes, R., Thieulle, L., Duru, M., Bouaziz, M., Pinson, A., Flora, F., Queneherve, P., Woignier, T., Allenou, J-P., Cimiterra, N., Benhalilou, A., Murgale, C., Maillet, T., Rangon, L., Chanteux, N., Chanteur, B., Béranger, C., Le Maho, Y., Petit, O. and Chevallier, D. (2018) Connecting paths between juvenile and adult habitats in the Atlantic green turtle using genetics and satellite tracking. Ecology and Evolution 8: 12790-12802. https://doi.org/10.1002/ece3.4708

Coimbra, Z.H., Assis, C.A., da Silva, V.M.F. and dos Santos, M.E. (2016) Mark-recapture abundance estimate of tucuxi dolphins (Sotalia fluviatilis) in a lake system of the Central Amazon. Marine Mammal Science 32(1): 241-251. https://doi.org/10.1111/ mms. 12254
Cremer, M.J. (2000) Ecology and conservation of Sotalia fluviatilis guianensis dolphin (Cetacea, Delphinidae) in Baia de Babitonga, north coast of Santa Catarina. M.Sc. Thesis. University Federal de São Carlos, São Carlos, Brazil. 226 pp.

Cremer, M.J., Hardt, F.A.S., Tonello Jr, A.J. and Simões-Lopes, P.C. (2011) Distribution and status of the Guiana dolphin Sotalia guianensis (Cetacea, Delphinidae) population in Babitonga Bay, northern Brazil. Zoological Studies 50(3): 327-337.

Crespo, E.A., Alarcon, D., Alonso, M., Bazzalo, M., Borobia, M., Cremer, M., Filla, G., Lodi, L., Magalhães, F.A., Marigo, J., Queiroz, H.L., Reynolds, J.E., Schaeffer, Y., Dorneles, P.R.J. and Wetzel, D.L. (2010) Report of the working group on major threats and conservation. Latin American Journal of Aquatic Mammals 8(1-2): 47-56. https://doi.org/10.5597/lajam00153

da Silva, V.M.F., Fettuccia, D., Rodrigues, E.S., Edwards, H., Moreno, I.B., Moura, J.F., Wedekin, L.L., Bazzalo, M., Emin-Lima, N.R., Carmo, N.A.S., Siciliano, S. and Utreras B.,V. (2010) Report of the working group on distribution, habitat characteristics and preferences, and group size. Latin American Journal of Aquatic Mammals 8(1-2): 31-38. https://doi.org/10.5597/lajam00151

Daura-Jorge, F.G., Rossi-Santos, M.R., Wedekin, L.L. and SimõesLopes, P.C (2007) Behavioral patterns and movement intensity of Sotalia guianensis (P.J. Van Bénéden) (Cetacea, Delphinidae) in two different areas on the Brazilian coast. Revista Brasileira de Zoologia 24(2): 265-270. https://doi.org/10.1590/S010181752007000200001

Daura-Jorge, F.G. and Simões-Lopes, P.C. (2016) Mark-recapture vs. line-transect abundance estimates of a coastal dolphin population: A case study of Tursiops truncatus from Laguna, southern Brazil. Latin American Journal of Aquatic Mammals 11(1-2): 133-143. https://doi.org/10.5597/lajam00222

Dawson, S.M., Wade, P., Slooten, E. and Barlow, J. (2008) Design and field methods for sighting surveys of cetaceans in coastal and riverine habitats. Mammal Review 38(1): 19-49. https://doi. org/10.1111/j.1365-2907.2008.00119.x

de Godoy, D.F., Andriolo, A. and de Filla, G.F. (2015) The influence of environmental variables on estuarine dolphins (Sotalia guianensis) spatial distribution and habitat used in the Estuarine Lagunar Complex of Cananéia, southeastern Brazil. Ocean and Coastal Management 106: 68-76. https://doi.org/10.1016/j. ocecoaman.2015.01.013

Delgado-Ortega, G. (2012) Distribución espacial y temporal de la Tonina del Lago (Sotalia guianensis) en la costa occidental del Sistema de Maracaibo. Ph.D. Thesis. University of Zulia. Maracaibo, Venezuela.

de Meirelles, A.C.O., Campos, A.A. and Fonteles-Filho, A.A. (2020) Occurrence, group size and site fidelity of Sotalia guianensis (Cetartiodactyla, Delphinidae) in an artificially sheltered beach in northern Brazilian coast. Pan-American Journal of Aquatic Sciences 15(2): 122-120.

de Mello, A.B., Molina, J.M.B., Kajin, M. and Santos, M.C.O. (2019) Abundance estimates of Guiana dolphins (Sotalia guianensis; Van Bénéden, 1864) inhabiting an estuarine system in southeastern Brazil. Aquatic Mammal 45(1): 56-65. https://doi.org/10.1578/ AM.45.1.2019.56

Domit, C., Caballero, S., Miranda, A., Fruet, P., Torres-Florez, J.P., Cunha, H., Farro, A.P., Azevedo, A., Bisi, T., Bricno, Y., Cremer, 
M.J., Tardin, R., Barreto, A.S, Bertozzi, C.P., Lailson Brito Jr, J., Barrios-Garrido, H., Van Belleghem, T., May-Collado, L., Di Tullio, J., Bracarense, A.P.L., Cantor, M. and Andriolo, A. (2019) Sotalia guianensis pre-assessment workshop: Main results and status of the current knowledge. Paper SC/68B/RE/05 presented to the Scientific Committee, International Whaling Commission, São Paulo, Brazil, 26-28 November 2019. [Available from the IWC website, <https://archive.iwc.int/>].

Domit, C., Miranda, A., Azevedo, A., Costa, A.F., de Meirelles, A.C.O., Farro, A.P., Bracarense, A.P.L., Barreto, A.S., Zaccaron, A.S., Andriolo, A., Louzada, C.N., Bertozzi, C.P., Kolesnikova, C., Marcondes, D.S., Ruenes, G., Melo-Santos, G., Cunhas, H., BarriosGarrido, H., Maciel, I., Lailson Brito Jr, J., Torres-Florez, J.P., di Tullio, J., Groch, K.R., May-Collado, L., Vidal, L.G., Flach, L., Sanchez, L., Bittencourt, L., Londono, M.C.R., Cremer, M.J., Alonso, M.B., Laeta, M., Cantor, M., Marmontel, M., Espinoza-Rodríguez, N.E., Fruet, P., Hauser-Davis, R., Sousa-Lima, R., Paitach, R., Tardin, R., Siciliano, S., Moura, S., Caballero, S., Bisi, T., Van Belleghem, T., Ridoux, V., Luz, V., Briceño, Y. and Le Pendu, Y. (2021) Progress report of the Sotalia guianensis Intersessional Group: Status of the current knowledge and action plan. Brazil, June 2021. 69 pp. https://www.researchgate.net/publication/352409783

Dussán-Duque, B.R. (2013) Ecology of the Guiana dolphin (Sotalia guianensis) in the Southern area of the Gulf of Morrosquillo, Colombia: implications for conservation. Ph.D. Thesis. University of St. Andrews, Scotland. 252 pp.

Edwards, H.H. and Schnell, G.D. (2001) Body length, swimming speed, dive duration, and coloration of the dolphin Sotalia fluviatilis (Tucuxi) in Nicaragua. Caribbean Journal of Science 37(3-4): 271-298.

Espinoza-Rodríguez, N.E., de Turris-Morales, K., Shimada, T. and Barrios-Garrido, H. (2019) Guiana Dolphin (Sotalia guianensis) in the southern Gulf of Venezuela: Seasonal distribution, group size, and habitat use. Regional Studies in Marine Science 32: 100874. https:/doi.org/10.1016/j.rsma.2019.100874

ESRI (2021) ArcGIS Desktop: Release 10.8. Environmental Systems Research Institute, Redlands, CA.

Filla, G. (2004) Estimate of population density and group structure of the gray dolphin Sotalia guianensis (Cetacea: Delphinidae) in Guaratuba Bay and in the north area of Complexo Estuarino da Baía de Paranaguá. M.Sc. Thesis. Universidade Federal do Paraná, Curitiba, Brazil. 97 pp.

Flach, L. (2015) Estimativa de parâmetros populacionais, área de vida, mortalidade e interações da atividade pesqueira sobre a população de Botos-Cinza (Sotalia guianensis) (Van Bénéden, 1864) na Baía de Sepetiba. Ph.D. Thesis. Universidade Estadual do Rio de Janeiro, Rio de Janeiro, Brazil. 151 pp.

Flores, P.A.C. and Bazzalo, M. (2004) Home ranges and movement patterns of the marine tucuxi dolphin, Sotalia fluviatilis, in Baía Norte, southern Brazil. The Latin American Journal of Aquatic Mammals 3: 37-52. https://doi.org/10.5597/lajam00047

Flores, P.A.C. and da Silva, V.M.F. (2009) Tucuxi and Guiana Dolphin: Sotalia fluviatilis and S. guianensis. Pages 1188-1192 in Perrin, W.P., Würsig, B. and Thewissen, J.G.M. (Eds) Encyclopedia of Marine Mammals. 2.ed. Academic Press, San Diego, USA. https://doi. org/10.1016/B978-0-12-373553-9.00271-6

Flores, P.A.C., da Silva, V.M.F. and Fettuccia, D.C. (2018) Tucuxi and Guiana dolphins: Sotalia fluviatilis and S. guianensis. Pages
1024-1027 in Würsig, B., Thewissen, J.G.M. and Kovacs, K. (Eds) Encyclopedia of Marine Mammals. 3.ed. Academic Press, San Diego, USA. https://doi.org/10.1016/B978-0-12-804327-1.00264-8

French Guiana Stranding Network (2020) Bilan annuel du Réseau des Echouages de Guyane. Pour la Direction de l'Environnement, de l'Aménagement et du Logement, Guyane française. 23 pp.

Garcia, C. and Trujillo, F. (2004) Preliminary observations on habitat use patterns of the marine Tucuxi, Sotalia fluviatilis, in Cispatá Bay, Colombian Caribbean coats. Latin American Journal of Aquatic Mammals 3(1): 53-59. https://doi.org/10.5597/lajam00048

Geise, L. (1991) Sotalia guianensis (Cetacea, Delphinidae) population in the Guanabara Bay, Rio de Janeiro, Brazil. Mammalia 55(3): 371-379. https://doi.org/10.1515/mamm.1991.55.3.371

Gensac, E. (2012) Dynamique morpho-sédimentaire d'un littoral sous influence amazonienne. Impact des forçages hydrosédimentaires sur la migration des bancs de vase et la mangrove côtière: le cas de la Guyane française. Ph.D. Thesis. Université du Littoral Côte d'Opale. Dunkerque, France. 215 pp.

Gomez-Salazar, C., Trujillo, F., Portocarrero-Aya, M. and Whitehead, H. (2012) Population, density estimates, and conservation of river dolphins (Inia and Sotalia) in the Amazon and Orinoco river basins. Marine Mammal Science 28(1): 124-153. https://doi. org/10.1111/j.1748-7692.2011.00468.x

ICMBio/MMA (2018) Livro Vermelho da Fauna Brasileira Ameaçada de Extinção: Volume II - Mamíferos. Instituto Chico Mendes de Conservação da Biodiversidade, Brasília, DF. 625 pp.

INSEE - Institut National de la Statistique et des Etudes Economiques (2019) Recensement de la population en Guyane. Ministère de l'Economie et des Finances, Paris, France. 9 pp.

IWC (2021) Report of the Scientific Committee. Report SC/68C, Scientific Committee, International Whaling Commission, Cambridge, UK, April-May 2021. 200 pp [Available from the IWC website, <https://archive.iwc.int/>].

Jauniaux, T., Garcia Hartmann, M., Haelters, J., Tavernier, J. and Coignoul, F. (2002) Echouage de mammifères marins: Guide d'intervention et procédures d'autopsie. Annales de médecine vétérinaire 146: 261-276.

Jean, C., Ciccione, S., Ballorain, K., Geogres, J-Y. and Bourjea, J. (2010) Ultralight aircraft surveys reveal marine turtle population increases along the west coast of Reunion Island. Oryx 44(2): 223-229. https://doi.org/10.1017/S003060530999072X

Kelle, L, Gratiot, N., Nolibos, I., Thérèse, J., Wongsopawiro, R. and de Thoisy, B. (2007) Monitoring of nesting Leatherback Turtles (Dermochelys coriacea): Contribution of remote sensing for real-time assessment of beach coverage in French Guiana. Chelonian Conservation and Biology 6(1): 142-147. https://doi. org/10.2744/1071-8443(2007)6[142:MONLTD]2.0.C0;2

Kiszka, J., Muir, C. and Jamon, A. (2007) Status of a marginal Dugong (Dugong dugon) population in the lagoon of Mayotte (Mozambique channel), in the western Indian Ocean. Western Indian Ocean Journal of Marine Science 6(1): 111-116. https://doi. org/10.4314/wiojms.v6i1.48230

Laake, J.L., Buckland, S.T., Anderson, D.R. and Burnham, K.P. (1993) Distance User's guide Version 2.0. Colorado Cooperative Fish Wildlife Research Unit, Colorado State University, Fort Collins, USA. 82 pp.

Lambert, C., Authier, M., Dorémus, G., Gilles, A., Hammond, P., Laran, S., Ricart, A., Ridoux, V., Scheidat, M., Spitz, J. and Van Canneyt, O. 
(2019) The effect of a multi-target protocol on cetacean detection and abundance estimation in aerial surveys. Royal Society Open Science 6: 190296. https://doi.org/10.1098/rsos.190296

Lobo, A.J., Wedekin, L.L., Sobral-Souza, T. and Le Pendu, Y. (2021) Potential distribution of Guiana dolphin (Sotalia guianensis): a coastal-estuarine and tropical habitat specialist. Journal of Mammalogy 102(1): 308-318. https://doi.org/10.1093/imammal/ gyaa153

Mannocci, L., Monestiez, P., Bolaños-Jiménez, J., Dorémus, G., Jeremie, S., Laran, S., Rinaldi, R., Van Canneyt, O. and Ridoux, V. (2013) Megavertebrate communities from two contrasting ecosystems in the western tropical Atlantic. Journal of Marine Systems 111-112: 208-222. https://doi.org/10.1016/j. jmarsys.2012.11.002

Monteiro-Neto, C., Ávila, F.J.C., Alves Jr, T.T., Araújo, D.S., Campos, A.A., Martins, A.M.A., Parente, C.L., Furtado-Neto, M.A.A. and Lien, J. (2004) Behavioral responses of Sotalia fluviatilis (Cetacea, Delphinidae) to acoustic pingers, Fortaleza, Brazil. Marine Mammal Science 20(1): 145-151. https://doi. org/10.1111/j.1748-7692.2004.tb01145.x

Nery, M.F., Espécie, M.A. and Simão, S.M. (2008) Site fidelity of Sotalia guianensis (Cetacea: Delphinidae) in Sepetiba Bay, Rio de Janeiro, Brazil. Revista Brasileira de Zoologia 25(2): 182-187. https://doi.org/10.1590/S0101-81752008000200004

Oshima, J.E.F. and Santos, M.C.O. (2016) Guiana dolphin home range analysis based on 11 years of photo-identification research in a tropical estuary. Journal of Mammalogy 97(2): 599-610. https://doi.org/10.1093/jmammal/gyv207

Rice, D.W. (2002) Classification. Pages 231-234 in Perrin, W.P., Würsig, B. and Thewissen, H. (Eds) Encyclopedia of Marine Mammals. Academic Press, San Diego, USA.

Rodríguez-Mahecha, J., Alberico, M., Trujillo, F. and Jorgenson, J., Eds (2006) Libro Rojo de los Mamíferos de Colombia. Serie Libros Rojos de Especies Amenazadas de Colombia. Conservación Internacional Colombia, Ministerio de Ambiente, Vivienda y Desarrollo Territorial, Bogotá, Colombia. 433 pp.

Rohtla, M. and Vetemaa, M. (2016) Otolith chemistry chimes in: migratory environmental histories of Atlantic tarpon (Megalops atlanticus) caught from offshore waters of French Guiana. Environmental Biology of Fishes 99: 8-9. https://doi.org/10.1007/ s10641-016-0501-1

Santos, M.C.O. and Rosso, S. (2007) Ecological aspects of marine tucuxi dolphin (Sotalia guianensis) based on group size and composition in the Cananéia estuary, southeastern Brazil. Latin American Journal of Aquatic Mammals 6: 71-82. https://doi. org/10.5597/lajam00110

Santos, M.C.O., Cremer, M.J., Secchi, E.R., Flach, L., Filla, G., Hubner, A. and Dussán-Duque, S. (2010) Report of the working group on population abundance and density estimation. Latin American Journal of Aquatic Mammals 8: 39-45. https://doi.org/10.5597/ lajam00152

Secchi, E., Santos, M.P. and Reeves, R. (2018) Sotalia guianensis. The IUCN Red List of Threatened Species. Available online https://
doi.org/10.2305/IUCN.UK.2018-2.RLTS.T181359A50386256.en Consulted on 31 May 2021.

Slooten, E., Dawson, S.M. and Rayment, W.J. (2004) Aerial surveys for coastal dolphins: Abundance of Hector's dolphins off the South Island west coast, New Zealand. Marine Mammal Science 20(3): 477-490. https://doi.org/10.1111/j.1748-7692.2004. tb01173.x

Tardin, R.H., Maciel, I.S., Espécie, M.A., Melo-Santos, G., Simão, S.M. and Alves, M.A.S. (2020) Modelling habitat use by the Guiana dolphin, Sotalia guianensis, in south-eastern Brazil: Effects of environmental and anthropogenic variables, and the adequacy of current management measures. Conservation Marine and Freshwater Ecosystems 30(4): 775-786. https://doi.org/10.1002/ aqc. 3290

Thomas, L., Buckland, S.T., Rexstad, E.A., Laake, J.L., Strindberg, S., Hedley, S.L., Bishop, J.R.B., Marques, T.A. and Burnham, K.P. (2010) Distance software: Design and analysis of Distance Sampling surveys for estimating populations size. Journal of Applied Ecology 47: 5-14. https://doi.org/10.1111/j.1365-2664.2009.01737.x

Trujillo, F., Crespo, E., Van Damme, P.A. and Usma, J.S. (2010) The Action Plan for South American River Dolphins 2010-2020. WWF, Fundación Omacha, WDS, WDCS, Solamac. Bogotá, D.C., Colombia. $249 \mathrm{pp}$.

UICN France, MNHN, GEPOG, Kwata, Biotope, Hydreco and OSL (2017). La Liste rouge des espèces menacées en France - Chapitres de la Faune vertébrée de Guyane. Paris, France. 77 pp. https://uicn. fr/wp-content/uploads/2019/02/rapport-evaluation-liste-rougefaune-vertebree-de-guyane-chapitre-mammiferes.pdf

UNEP (2008) Action Plan for the Conservation of Marine Mammals (MMAP) in the Wider Caribbean Region. 39 pp. [Available from the website of the Regional Activity Centre for the Protocol Concerning Specially Protected Areas and Wildlife for the Wider Caribbean Region <https://www.car-spaw-rac.org/lMG/pdf/ mmap.pdf $>$ ]

Van Waerebeek, K. (1990) Preliminary notes on the existence of a dolphin by-catch off French Guiana. Aquatic Mammals 16(2): 71-72.

Vidal, O., Barlow, J., Hurtado, L.A., Torre, J., Cendón, P. and Ojeda, Z. (1997) Distribution and abundance of the Amazon River dolphin (Inia geoffrensis) and the Tucuxi (Sotalia fluviatilis) in the upper Amazon River. Marine Mammal Science 13(3): 427-445. https:// doi.org/10.1111/j.1748-7692.1997.tb00650.x

Williams, R., Leaper, R., Zerbini, A.N. and Hammond, P.S. (2007) Methods for investigating measurement error in cetacean linetransect surveys. Journal of the Marine Biological Association of the United Kingdom 87: 313-320. https://doi.org/10.1017/ S0025315407055154

Williams, R., Ashe, E., Gaut, K., Gryba, R., Moore, J.E., Rexstad, E., Sandilands, D., Steventon, J. and Reeves, R.R. (2017) Animal counting toolkit: a practical guide to small-boat survey for estimating abundance of coastal marine mammals. Endangered Species Research 34: 149-165. https://doi.org/10.3354/esr00845 